\title{
Introduction to The China Model: Political Meritocracy and the Limits of Democracy
}

\author{
Daniel A. Bell \\ Professor and Dean of the School of Political Science and Public \\ Administration, Shandong University, China \\ bei@sdu.edu.cn
}

The idea that political leaders should be chosen according to one person, one vote is taken for granted in so many societies that any attempt to defend political meritocracy should begin with a critique of electoral democracy: most readers in Western societies won't even be willing to contemplate the possibility of morally justifiable alternatives to one person, one vote as a means of selecting political leaders, so a book arguing in favor of an alternative must at least raise some questions about democratic elections. ${ }^{1}$ Some philosophers have defended the rights to vote and run for office on the grounds that political liberties are intrinsically valuable for individuals whether or not they lead to collectively desirable consequences. These arguments, however, have been vigorously contested. And if the aim is to promote electoral democracy in China, arguments for democracy appealing to the intrinsic value of voting will not be very effective because political surveys consistently show that citizens in East Asian societies understand democracy in substantive rather than procedural terms: that is, they tend to value democracy because of its positive consequences rather than valuing democratic procedures per se. So the politically relevant question is whether democratic elections lead to good consequences. Democracy has had a good track record over the past few decades: rich, stable, and free countries are all democratic. But democracies also have key flaws that may spell political trouble in the future, and it is at least arguable that political meritocracies can minimize such problems.

1 Reprinted from The China Model: Political Meritocracy and the Limits of Democracy by Daniel A. Bell (Princeton University Press, 2015), with permission. Daniel A. Bell has published several books on East Asian politics and philosophy and he is the founding editor of the Princeton-China series. His works have been translated into 23 languages. 
Chapter $1^{2}$ of the book The China Model: Political Meritocracy and the Limits of Democracy ${ }^{3}$ discusses four key flaws of democracy understood in the minimal sense of free and fair elections for the country's top rulers, and each flaw is followed by a discussion of theoretical and real meritocratic alternatives. The first flaw is "the tyranny of the majority": irrational and self-interested majorities acting through the democratic process can use their power to oppress minorities and enact bad policies. Examinations that test for voter competence can help to remedy this flaw in theory, and Singapore's political meritocracy is a practicable alternative. The second flaw is "the tyranny of the minority": small groups with economic power exert disproportionate influence on the political process, either blocking change that's in the common interest or lobbying for policies that benefit only their own interest. In theory, this flaw can be remedied by means of a citizen body that excludes wealthy elites, and China's political system is a practicable alternative. The third flaw is "the tyranny of the voting community": if there is a serious conflict of interest between the needs of voters and the needs of nonvoters affected by the policies of government such as future generations and foreigners, the former will almost always have priority. One theoretical remedy is a government office charged with the task of representing the interests of future generations, and Singapore's institution of a president with the power to veto attempts by politicians to enact policies that harm the interests of future generations is a practicable alternative. The fourth flaw is "the tyranny of competitive individualists": electoral democracy can exacerbate rather than alleviate social conflict and disadvantage those who prefer harmonious ways of resolving social conflict. A system based on consensus as a decision-making procedure can help to remedy this flaw, and China's political model has some practical advantages in terms of reducing social conflict.

In short, there may be morally desirable and political feasible alternatives to electoral democracy that help to remedy the major disadvantages of electoral democracy. If the aim is to argue for political meritocracy in a Chinese context, however, we do not need to defend the strong claim that political meritocracy consistently leads to better consequences than electoral democracy. We can simply assume that China's one-party political system is not about to collapse and argue for improvements on that basis. Chapter 2 proceeds on the following assumptions: (1) it is good for a political community to be governed

2 This and all subsequent references are to chapters in The China Model, not to specific content in this issue of Journal of Chinese Humanities.

3 Daniel Bell, The China Model: Political Meritocracy and the Limits of Democracy (Princeton: Princeton University Press, 2015). 
by high-quality rulers; (2) China's one (ruling) party political system is not about to collapse; (3) the meritocratic aspect of the system is partly good; and (4) it can be improved. On the basis of these assumptions, I draw on social science, history, and philosophy to put forward suggestions about which qualities matter most for political leaders in the context of large, peaceful, and modernizing (nondemocratic) meritocratic states, followed by suggestions about mechanisms that increase the likelihood of selecting leaders with such qualities. My findings about which abilities, social skills, and virtues matter most for political leaders in the context of a large, peaceful, and modernizing political meritocracy are then used as a standard for evaluating China's actually existing meritocratic system. My conclusion is that China can and should improve its meritocratic system: it needs exams that more effectively test for politically relevant intellectual abilities, more women in leadership positions to increase the likelihood that leaders have the social skills required for effective policy making, and more systematic use of a peer-review system to promote political officials motivated by the desire to serve the public.

Any defense of political meritocracy needs to address not only the question of how to maximize the advantages of the system but also how to minimize its disadvantages. Chapter 3 discusses three key problems associated with any attempt to implement political meritocracy: (1) rulers chosen on the basis of their superior ability are likely to abuse their power; (2) political hierarchies may become frozen and undermine social mobility; and (3) it is difficult to legitimize the system to those outside the power structure. Given that electoral democracy at the top is not politically realistic in China, I ask if it is possible to address these problems without democratic elections. The problem of corruption can be addressed by mechanisms such as independent supervisory institutions, higher salaries, and improved moral education. The problem of ossification of hierarchies can be addressed by means of a humble political discourse, opening the ruling party to diverse social groups, and allowing for the possibility of different kinds of political leaders selected according to new ideas of political merit. The problem of legitimacy, however, can be addressed only by means of more opportunities for political participation, including some form of explicit consent by the people. The question, therefore, is how to reconcile political meritocracy and democracy. Can it be done in morally desirable ways without multiparty competition and free and fair elections for top leaders?

Chapter 4 discusses the pros and cons of different models of "democratic meritocracy": more specifically, models that aim to reconcile a meritocratic mechanism designed to select superior political leaders with a democratic mechanism designed to let the people choose their leaders. 
The first model combines democracy and meritocracy at the level of the voter (e.g., allocating extra votes to educated voters), but such proposals, whatever their philosophical merit, are not politically realistic. The second (horizontal) model aims to reconcile democracy and meritocracy at the level of central political institutions, but such a model will be almost impossible to implement and sustain even in a political culture (such as China's) that strongly values political meritocracy. The third (vertical) model aims to combine political meritocracy at the level of the central government and democracy at the local level. This model is not a radical departure from the political reality in China and it can also be defended on philosophical grounds.

The political model in China, however, is not simply democracy at the bottom and meritocracy at the top: it is also based on extensive and systematic experimentation in between the lowest and highest levels of government. The concluding chapter sketches out three basic planks of the China model and shows how political reform in the post-Mao era has been guided by the principles of "democracy at the bottom, experimentation in the middle, and meritocracy at the top." There remains a large gap between the ideal and the reality, however, and I suggest ways of closing that gap. The legitimacy problem is perhaps the most serious threat to the meritocratic system. At some point, the Chinese government may need to secure the people's consent to the Chinese adaptation of vertical democratic meritocracy by means such as a referendum. The chapter ends with remarks about the exportability of the China model: while the model as a whole cannot readily be adopted by countries with a different history and culture, different planks of the model can be selectively adopted and the Chinese government can play a more active role promoting its model abroad.

This book's central area of concern is the question of how to maximize the advantages and minimize the disadvantages of a political system that aims to select and promote political leaders of superior virtue and ability, particularly in the contemporary Chinese context. Other than arguing for the need to enact policies that benefit the people, I have been deliberately vague about what those leaders should do: China is a large, complex country with different needs and priorities in different times and places, and any informed answer needs to be partly based on what the Chinese people actually want. That said, some general guidance may be helpful and the book includes two appendixes published online at http://press.princeton.edu/titles/10418.html. The first appendix is a Harmony Index that ranks countries according to how well they do at promoting four different types of social relations characterized by peaceful order and respect for diversity. This kind of index, either in part or in whole, can be used to judge social progress (and regress) in China and elsewhere. Another possible 
use of the Harmony Index more specific to the Chinese context is that it can be considered as a standard to judge the performance of political officials for purposes of promotion (or demotion), especially given the widespread consensus that economic growth can no longer be used as the sole indicator of good performance.

The second appendix is a real political dialogue (carried out in person and via email) with a political official in the [Chinese Communist Party]. My own ethical commitments are largely inspired by Confucian values, but I do not think that Confucianism is the only way to justify political meritocracy, so I have not been too explicit about the empirical and normative relevance of Confucianism in this book. Still, Confucianism can influence how one thinks about political meritocracy, and the second appendix focuses more directly on the role of Confucianism in shaping China's political meritocracy. The dialogue is a rare window into the views of an erudite CCP official who is speaking in a private capacity. The appendix is titled "A Conversation between a Confucian and a Communist," but by the end of the dialogue it will not be clear who's who.

\section{Works Cited}

Bell, Daniel [Bei Danning 貝淡寧]. The China Model: Political Meritocracy and the Limits of Democracy. Princeton: Princeton University Press, 2015. 